\title{
Rendering the Popular as "Tradition": The Music of Virgilio "Pirot" Petcheller and the Panay Bukidnon Banda Music Practice in Panay Island, Philippines
}

\author{
Jose R. Taton Jr. \\ University of the Philippines Visayas, Philippines \\ General Luna Street, Iloilo City \\ e-mail: jrtaton@up.edu.ph \\ *Corresponding author: jrtaton@up.edu.ph
}

Published: 20 October 2020

Cite this article (APA): Taton, J., Jr. (2020). Rendering the popular as "tradition": The music of Virgilio "Pirot" Petcheller and the Panay Bukidnon banda music practice in Panay Island, Philippines. Malaysian Journal of Music, 9, 65-81. https://doi.org/10.37134/mjm.vol9.6.2020

\begin{abstract}
In recent years, the popular music of Virgilio "Pirot" Petcheller had been included in the banda (ensemble) musical repertoire, practice and identity of several indigenous cultural communities in Panay Island located in Western Visayas, Philippines. Pirot's music, particularly renderings of folk music genres, such as harana (serenade) and komposo (ballad), had been in mainstream broadcast media and were widely produced by the recording industry in the 1970s. Because of the parallels between his music and West Visayan folk practice, folk musicians categorically ascribe and recognise his music as dinuma-an (tradition and traditional) to refer to a standard folk canon with an associated pastoral imagery. Later, Pirot's music had become emblematic of a regional folk, cultural and/or ethnic identity. This paper investigates the problematic fluidity of boundaries between traditional and popular music categories and its implications in the construction of identity in the Western Visayan context. I examine, on the one hand, how the popular music of Pirot are rendered as "tradition" notably through a discussion on musical aesthetics, lyricism and imagery and the complex socio-cultural and historical context musicians occupy. On the other hand, this paper also proffers a discussion on how this rendering or "traditionalisation" plays a role in the construction of identity among the Panay Bukidnon banda musicians. On this, I recognise the central role of cultural praxis and individual agency in the process and argue that musical categories, particularly the notion of 'tradition' and 'traditional', are self-conscious devices defined by, and are constitutive of practice.
\end{abstract}

Keywords: banda, Panay Bukidnon, Pirot, popular music, traditionalisation

\section{Introduction}

Thinking about folk music in Western Visayas region in the Philippines, it is illustrative to invoke the "creative persona" of Virgilio G. Petcheller, a popular music performer, composer and recording artist in the region. Known to many as "Pirot", Petcheller entered the radio and recording industry circuit in the 1970s with his renderings of harana, a type of serenade that is typically sung by men during courtship sprees, and komposo, a ballad that narrates significant community events using real-life situations or allegories (Cainglet, 1981). Through his songs, Pirot had dominated the regional popular music scene of his time captivating the imagination of a generation of radio listeners that his name had already become synonymous with folk music in the typical urban and rural household.

Today, his music remains current and significant to generations of folk performers, particularly among banda (string and percussion ensemble) musicians in several indigenous cultural communities 
in Panay Island. While it is generally considered as "popular music" for its association with the music industry, Pirot's music is also categorically recognised as dinuma-an vis-à-vis its links to Western Visayan folk genres (as tradition) and its vestigial and pastoral aura (as traditional). For many banda performers, particularly those coming from rural and indigenous communities in Panay (Figure 1), Pirot's music evokes the spirit of the past and, in turn, had become illustrative of their native culture, local heritage and sense of being. Banda musicians have thus by far identified, utilised and performed selections of Pirot's music as personal and collective articulations of ethnicity and regional identity.

Considering the manner folk musicians employ Pirot's music in the context of tradition and identity, several questions come into mind. How do renderings of folk music in the popular works of Pirot inform banda musicians of their notions of "tradition" and "traditional" in music? What musical and socio-cultural parameters have contributed to the way musicians think about musical categories? How is this notion articulated in the context of agency and construction of identity? This paper investigates the problematic fluidity of meaning in music categories and its implications in the construction of identity. Using musical ethnography and fieldwork in various Panay indigenous communities in Western Visayas from 2015 to 2020, I discuss, on the one hand, how the popular music of Virgilio "Pirot" Petcheller was rendered and categorised as dinuma-an by examining the musical aesthetics, lyricism and imagery in Pirot's music to understand its association and possibly conflation with folk music genres. On the other hand, I discuss how this rendering or what I call "traditionalisation" informed the construction of regional indigenous identity in relation to the complex socio-cultural and historical context of banda communities. I recognise the central role of cultural praxis and individual agency in the process and argue that musical categories, particularly the notions of "tradition" and "traditional", are self-conscious devices defined by and is constitutive of practice.
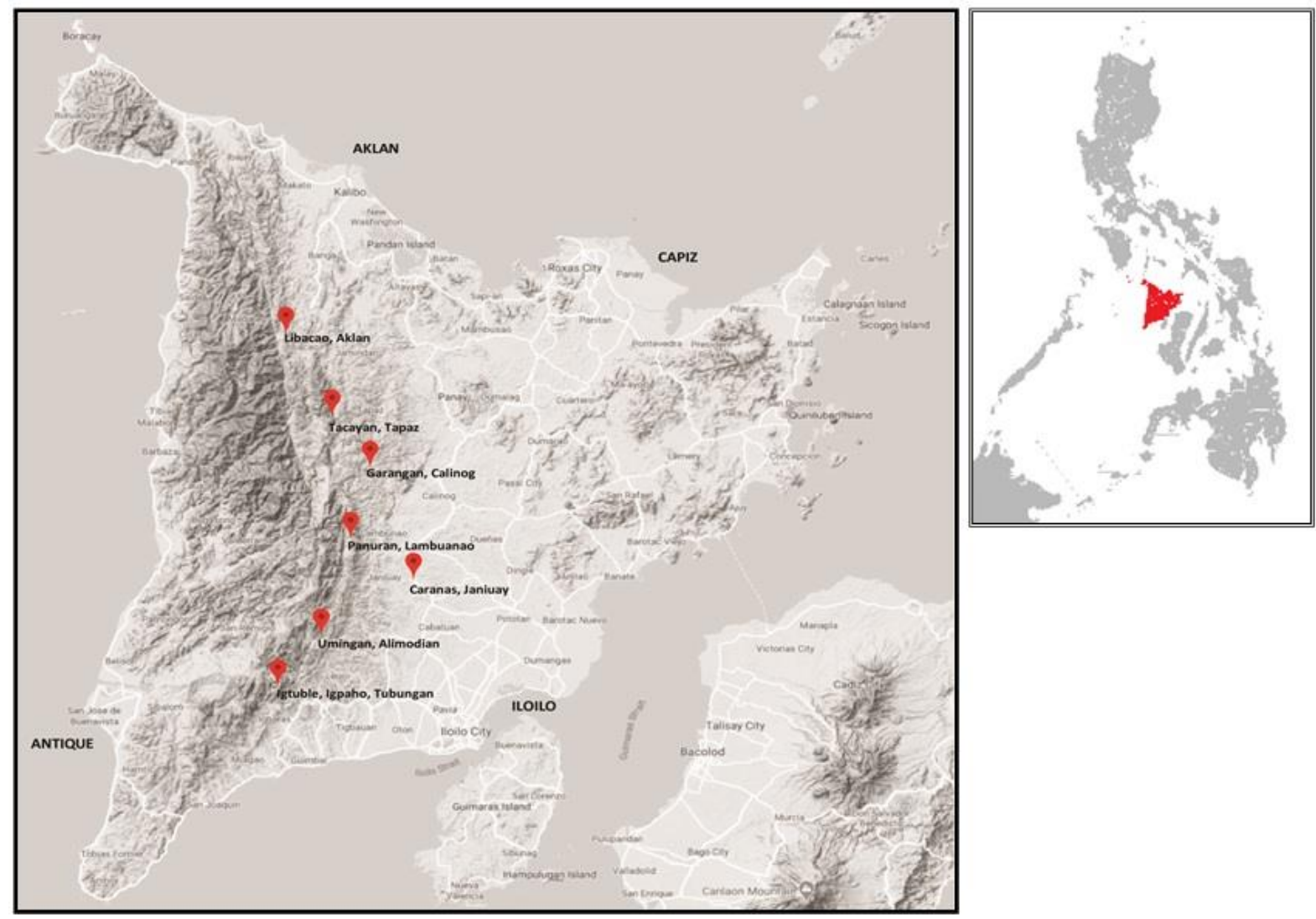

Figure 1. Some areas with active banda groups in Panay Island, Philippines. ${ }^{1}$ 


\section{The Banda in Panay and the Music in Popular Media}

Located in Western Visayas, Philippines, Panay Island is a rich cultural hearth of folk music ensembles. Collectively known as banda, these travelling musicians are found in rural and indigenous communities across the island's four provinces of Antique, Akan, Capiz and Iloilo. They are considered vital in the social life of the community performing special musical functions specifically in ceremonial activities which include marriages, funeral services and healing rites, as well as in civic events like the patronal fiesta (feast day of saints) celebration and the community bayle (dance ball) (Doromal, 1988).

The banda is a group of string and percussion musicians who play a number of instruments which include the following: biyulin (violin), bandyo (banjo), bandyolina (banjolin), gitara (guitar), baho (string bass), bombo (bass drum), barabadang (snare drum) and mangmang (hand-held cymbals). Its composition is typically composed of at least three musicians comprised of a principal who plays the puntiyar (lead) instrument, usually assigned either to the biyulin or bandyo, and complemented by at least two members who provide the kompanyar (accompaniment) (Figure 2). In some other cases, banda musicians may also render songs as they are also distinguished vocalists.

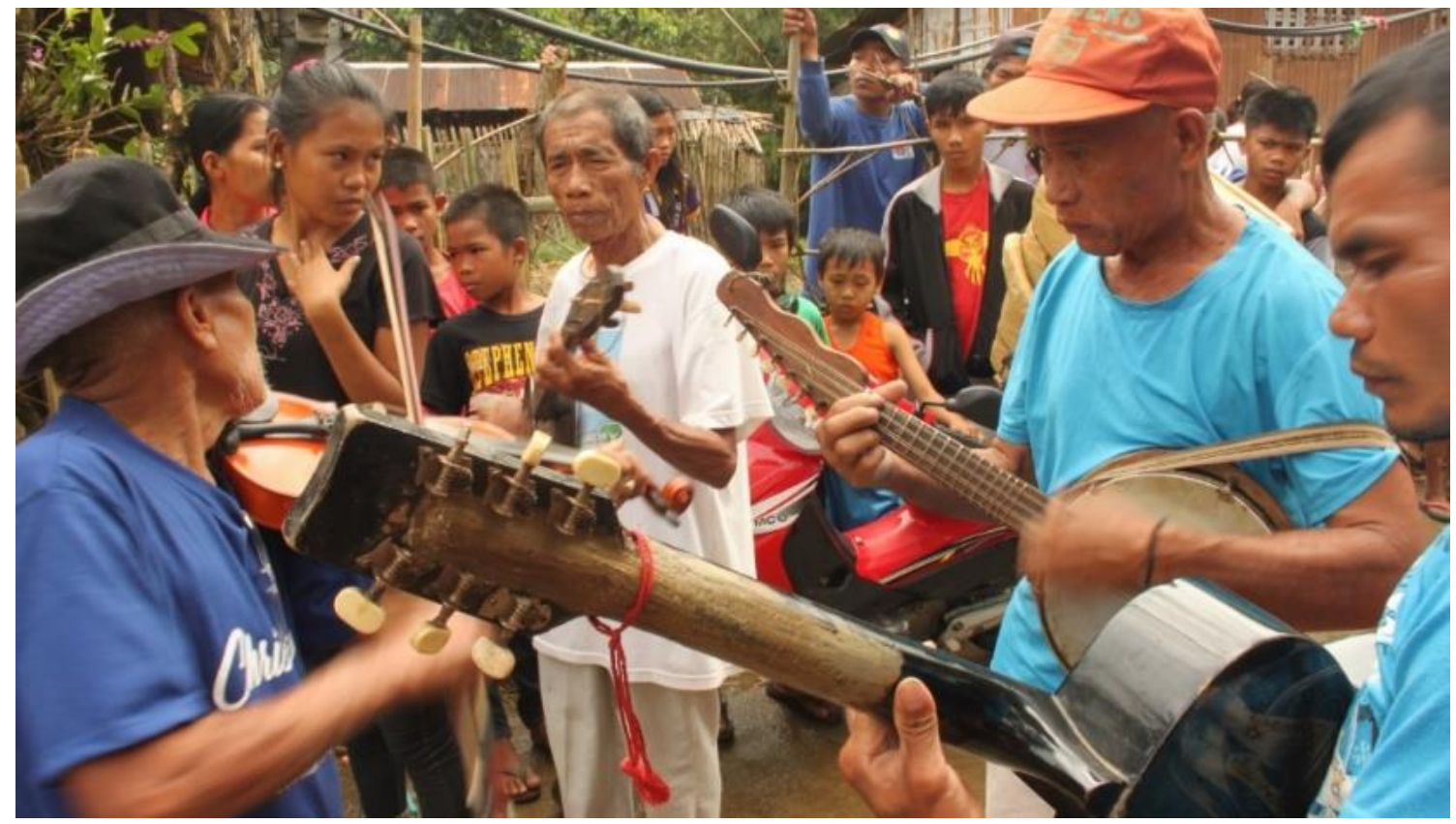

Figure 2. A local banda in an indigenous cultural community in Tubungan, Iloilo.

As professional entertainers, the banda performs sets of musical pieces which range from the folk category represented by Western Visayan genres like the harana (serenade), komposo (ballad) and banggianay (poetic joust) to a number of popular music compositions that had once circulated via mass media and the music industry. This amalgamation of musical material, particularly in terms of the ensemble's instrumentation, repertoire and aesthetics, is the result of the complex junctures in Philippine colonial history.

As early as the sixteenth century, European and Latin American instrument technology had already reached the Philippines via the transpacific galleon trade (Irving, 2010). This diffusion of instruments was likely the result of the migration of craftsmen, among them included luthiers, from Mexico to the Philippines who had a primary impact in the production and distribution of instruments in the archipelago (Guzman-Bravo, 1978; Stevenson, 1971). Among the early instruments imported or produced in the country were harps, guitars, violins and bandurria (plucked string lute), some of which were incorporated in music ensembles like the estudiantina (student instrument performers) (Pfeiffer, 1975), rondalla (plucked string ensemble), professional comparza (string band) (Rubio, 1977) and combo music bands centuries later (Doromal, 1988). Meanwhile, brass band instruments were largely introduced in Spanish military regiments in the eighteenth century (Talusan, 2009). Up until the twentieth century, the instrumental music groups were central in celebrations that marked the 
community religious and civic calendars (Hila, 1989), in festive occasions, stately opera concerts and zarzuela (musical theatre) presentations in the region (Fernandez, 1978). On the other hand, the Americans could have likely introduced folk banjo music in the country initially as a bourgeois music activity and later as a folk symbol. ${ }^{2}$

On repertoire, musico-poetic song genres like the komposo (ballad) and the harana (serenade) reminiscent of Spanish dodecasyllabic and octosyllabic poetic quatrains were largely popular pieces among folk ensembles (Tan, 1981). Traces of Hispanic and Latin-inspired dances, such as the fandango, jota and curacha, and even of American swing, ragtime, Charleston, tango, and waltz were also staples in the repertoire as well (Canave-Dioquino, et al., 2008). The resulting "counterpoint" of native and colonial elements, echoing Irving's idea on the convergence of musical cultures (2010), became evident in vernacularised folk dance practices, and in Panay Island, with versions of kuratsa (Fajardo, 1961; Suarez, 1971), sarleston (Colon, n.d.), danza (Cainglet, 1981) and sayaw sword-play wedding ritual music (Taton, 2019).

After the Second World War, rapid modernisation in urban centres afforded the circulation of locally and internationally produced sound materials. In the province of Iloilo and across the island of Panay, for instance, the expanded coverage of radio and other forms of mass media enabled new music like American rock and roll to seep in within folk and rural communities. This broadly diversified the musical palette of the banda musicians, apparently, to become more modern and progressive, which, by and large, transformed the constitution of their musical repertoire. Meanwhile, the mass production of vinyl records and battery-operated gramophones called pono, provided the mass public limitless access to popular music recordings. Unlike real-time broadcasts and performance-based music-making, the option for unlimited listening with the machine's playback feature made better recall to new waves of music styles. Because of these changes, the putative significance of genres like the komposo and harana as news and courtship outlets were gradually discounted and inadvertently replaced with streamed radio announcements and foreign popular music. Mass media had opened avenues for musical innovations, expanded local musical tastes and changed the music consumption behaviour of the rural folk.

The subsequent musical and cultural changes modernity had wrought, however, sparked a strong nostalgia in metropolitan centres and, in turn, animated a consciousness that idealised folk music and traditions of the past. Public petitions to resuscitate "traditional" song repertoire ignited the folk music "revival" initiative in the 1960s until the 1980s (Tan, 1981). As a result, numerous radio stations like DYCO in 1964-66, DYRP in 1969-69 and DZFM in 1974-81 provided a platform where regional "folk" music and locally-inspired compositions were regularly streamed (Tan, 1981). Radio programmes featured live performances of prolific local harana and komposo singers, like Virgilio "Pirot" Petcheller among others, and had substantively re-popularised the "traditional" and "folk" music in the region. ${ }^{3}$ Through mass media, innovations on harana and komposo music, such as the music of Pirot, became mainstream and consequently were taken up by banda musicians for their performances.

\section{Pirot, the Haranista}

Dubbed as Iloilo's premier haranista, Virgilio Petcheller or Pirot is one of the many prolific folk musicians in the province of Iloilo and the Visayas region (Figure 3). Born in Lemery, Iloilo in 1954, Pirot is the eldest child among seven siblings. In his early years, he had already shown enormous interest in music likely from his early exposure to diverse musical influences. Aside from being born in a musically-inclined family, he was already immersed in biyulin, bandyo and guitar music repertoire from a local musician, Sergio "Telong" Cabacas. Moreover, he had also enriched his innate ability for singing through his strong habit of listening to popular music on the radio. After finishing primary school, he had joined in and had won various local singing competitions performing American popular music as well as folk tunes. 


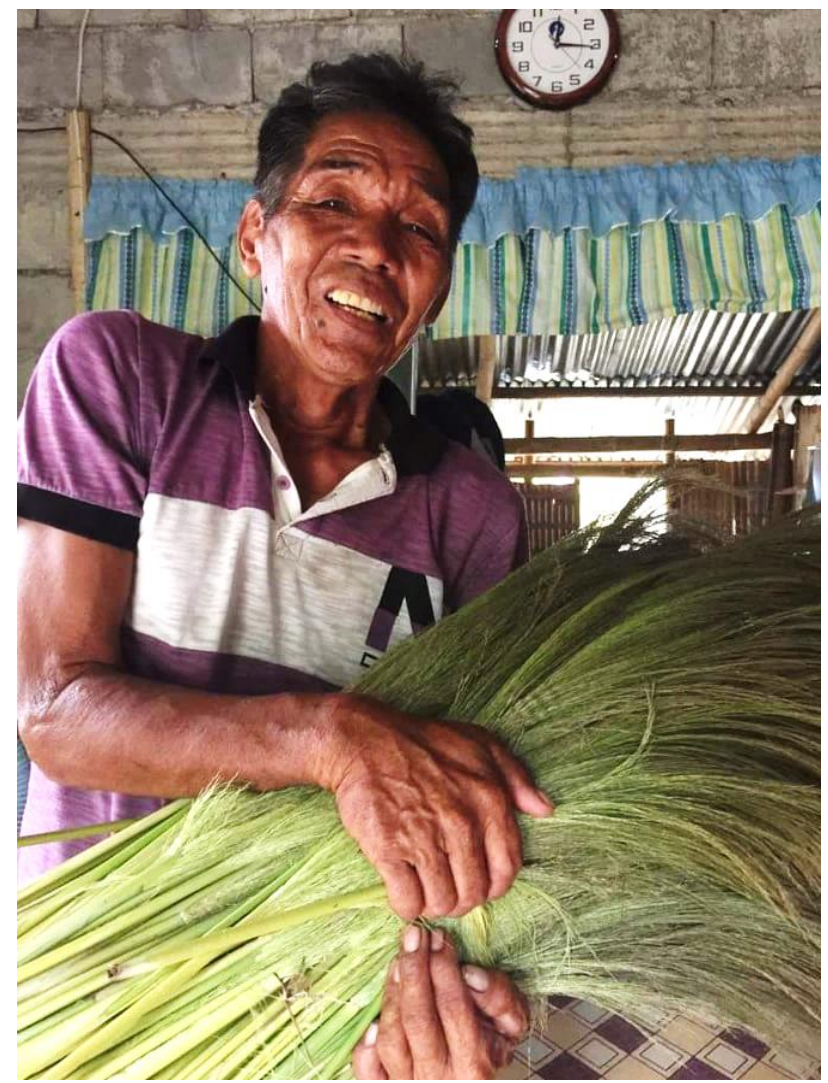

Figure 3. Virgilio "Pirot" Petcheller.

Pirot's teenage years had also been musically productive. At seventeen, he had already learned how to play the guitar on his own at a time when harana (serenade) was quite popular among men his age. Using stock phrases used in banggianay (poetic jousts) ${ }^{4}$ and the harana tunes he had heard from his maternal grandfather, he would carouse young women or put up against his fellows in a jocularly competitive display of wit and exchange of poetic verses. Because of these nightly jaunts, Pirot had significantly improved, if not become adept, not only in his musical sensibilities but also in his skills in the spontaneous invention of verses. These experiences would soon prove valuable in his career much later.

In 1976, Pirot, who was then just twenty-two, made his radio debut as a regular talent in the DYFM Bombo Radyo programme, Harana, hosted by radio anchor Eddie K. Suede. At work, he had collaborated with other prolific folk singers like Ismael Payupay, Nards de Llero, and Jasmin Ceballos. However, his partnership with Alma Villanueva, a versatile Ati vocalist, in live broadcasts of banggianay and harana performances became a popular segment in the programme which attracted a huge following not just in Metro Iloilo but across Western Visayas. ${ }^{5}$ Their synergy largely contributed to Pirot's success as a performing artist in the regional music industry.

Notwithstanding the popularity of other folk musicians performing locally and regionally, Pirot stood out among others because of his exceptional vocal style. Compared to the musical humour distinct to composers/performers in the region like Yoyoy Villame and Max Surban (Buenconsejo, 2019), Pirot exhibits an inimitable vocal style that has a rich undulating low-pitch timbre described by many as mabugnaw (calming). With this vocal quality, Pirot evokes among his listeners particular rustic imagery and pastoral sentimentality which suit the lyrical and musical requirements typical of harana and komposo music.

Pirot's golden age in the recording industry happened in 1978. This time, he worked with a number of composers as well as music producers for several projects. ${ }^{6} \mathrm{He}$ signed his first $45 \mathrm{RPM}$ under the distributing company Platinum Records with the hit song "Ako Ang Namunit" (I Catch Fish) and "Mabugnaw Ang Lasang" (The Forest is Cool). In just a few weeks, another RPM with the titles, "Kampo Ni Ladio" (Ladio's Camp) and "Mapintas Nga Damgo" (A Cruel Dream) followed after the 
initial success of the first record. Shortly, in the same year, a long-play (LP) album featuring Ilonggo works was released.

Seeing the prospect of enlarging the balladeer's audience and popularity across the provinces in Visayas and Mindanao as well as in urban Tagalog regions in Luzon, Suede contracted Pirot to record his hit singles in the Bisaya/Cebuano and Tagalog languages. In the last quarter of 1978, another LP was produced which is comprised of songs translated to Cebuano. Moreover, under the Jubell Label, new RPMs of Tagalog compositions like "Ako Si Virginio" (I am Virginio) and Ibang-Iba Ka Talaga" (You are Exceptional) were also widely circulated. Similarly, Leira Records also produced some song translations. Additional LPs which contained Tagalog and Cebuano renditions, like "Pirot" and "Stow Away Ako", were also distributed to the market (Figure 4).

In these recordings, Pirot covered a diverse set of musical styles encompassing a broad range of themes: historical komposo, such as "Purchase of Panay,"1978; character-based komposo, like "Tamasak" (A Horse), 1978; renditions of traditional folk melodies, such as "Kanogon" (Oh, Woe!), 1978, and its Tagalog version, "Sayang Na Sayang" (What a Waste), 1978; and a variety of harana music which he is known for among others. As a recording artist, Pirot had demonstrated a remarkable versatility as a popular entertainer who can perform for a variety of audiences and can shift along with different music genres.

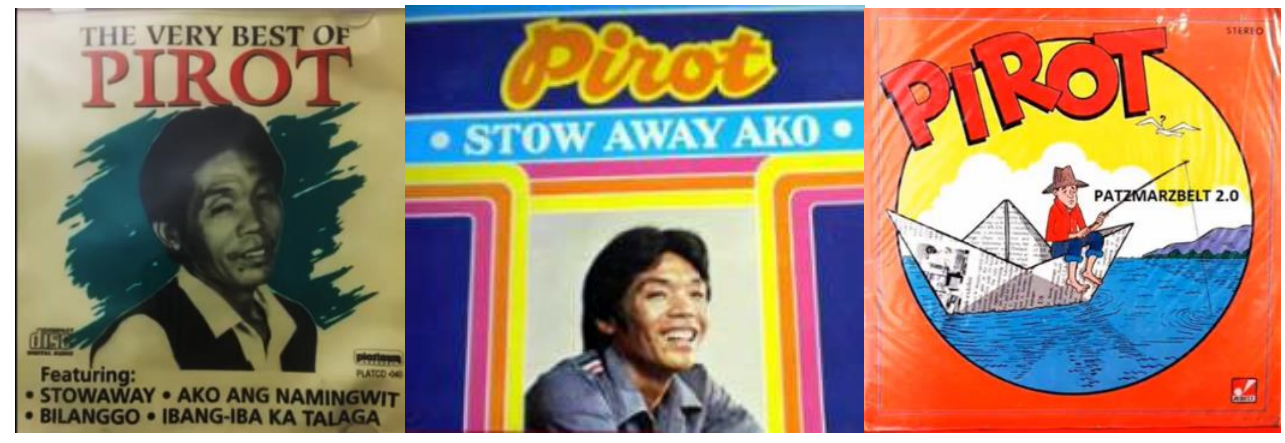

Figure 4. Collage of covers of some of Pirot's recordings. ${ }^{7}$

Urban Iloilo, indeed, offered Pirot an experience that transcended the limited possibilities of village life. After six years in the performing and recording industry, he had already established a name for himself as Iloilo's premier and most celebrated haranista. His regular radio program amassed a huge following not just within urban Iloilo but also in remote areas in the province. His public performances in front of then Freedom Grandstand (now Sunburst Park) always drew in a crowd that expected a delightful nightly soiree of musical wit and humour. However, with the unstable cultural and political climate in Iloilo in the early 1980s compounded by personal socio-economic challenges, Pirot returned to the tranquil world of family life.

Despite his absence in the broadcast industry for more than a decade, Pirot had still sustained some creative work in the music industry. As a performer, he had been a frequent guest in several local radio broadcast programs. He had also participated in a number of concerts regionally as well as in performances in some cities in the southern island of Mindanao. As a recording artist, he had collaborated with his eldest son, Regie, in a record album under Platinum in 1994. Here, a number of new komposo works were introduced, most notably "Barumbado" (Irresponsible). In 2009, he had selfproduced an album together with his youngest son, Joven. This particular album specially featured a traditional banggianay (poetic joust), titled "Bulak Nahamut-an" (A Woman to Please) and dancemusic, "Idog-Idog" (Move to the Side). The constrictions of village life, however, made a strong dent on how he composed his song verses. Pirot would compose titles that captured the antimodernist aesthetic and pastoral realities all connected to the values and struggles of Filipino folklife.

Moreover, Pirot had also run radio programmes in various stations, in particular, "Mga Bahandi Na Ambahanon" (Cherished Songs) in DYOK Aksyon, 1994-1998; in DYRI RMN, 2006-2009; and in DYSI GMA in 2010. In 2010, he was given the Pinoy Icon Award by a national news network. Early in 2019 , he became involved in a weekly social media live stream broadcast. 


\section{Pirot's Music and Folk Aesthetics}

The success of Pirot's songs in the music industry is imputed to their close affinity with folk music aesthetics. Pirot's music resembles a wide range of existing traditional melodic formulas familiar to many generations of listeners. It also applies the general Ilonggo and Western Visayan folk music aesthetics where musical motifs are typically composed in a shifting minor-major tonality (commonly parallel), set in a simple harmonic organisation and structured in a strophic form (Cainglet, 1981). In conventional practice, these stock tunes may be used in various performances where, instead of a unique melody, freshly penned lyrics shape the character of a new composition. Pirot exemplified this in the songs "Mabugnaw and Lasang" and "Ako Si Virginio" (Figure 5).

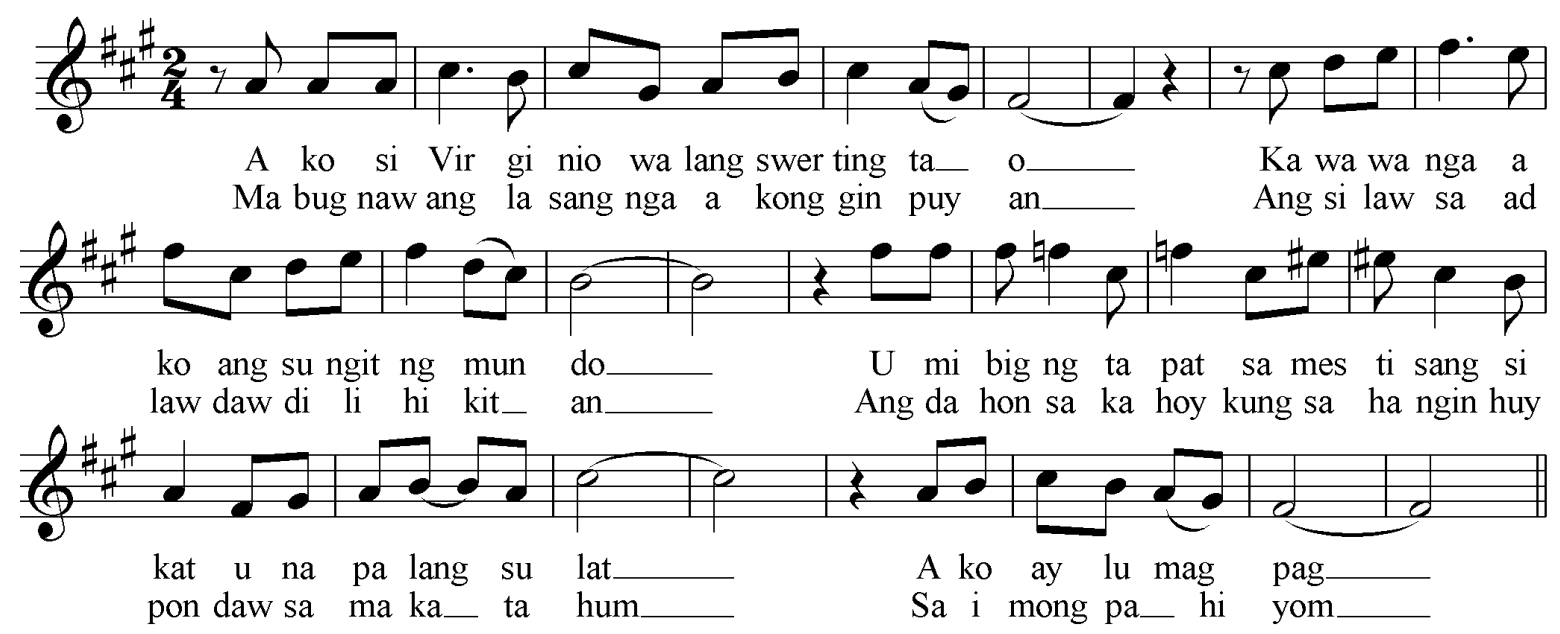

Figure 5. A common melodic formula in some of Pirot's songs.

In lyricism, Pirot's "new" music follows how folk verses are traditionally structured. Pirot's renditions of komposo (ballad), such as "Ako Ang Namunit", demonstrates the usual twelve-syllable phrase structure divided equally by a short caesura (pause) employed in Western Visayan ballads. In a seminal work on the composo, Tan (1981) explains that a typical Hiligaynon ballad is composed of dodecasyllabic and octosyllabic quatrains. Equally, some of his banggianay and harana music also employs the same system of versification suggesting his intimate understanding, natural eloquence and linguistic fluency to these musico-poetic forms.

Besides these, Pirot's works are also rich with imaginative yet playful lyricism that allude to and render images of the village and its social and life cycles. To illustrate, a number of his serenades and ballads profusely utilise metaphorical and allegorical devices which thread through a range of themes such as unrequited love, estranged family and forbidden social relations. For example, in "Ako Ang Namunit", Pirot characterises love as a fateful voyage full of uncertainties.

Ako ang namunit sa pampang sang gugma

Ang akon ginpaon madamo na letra

Baroto ginsakyan sang sobre na rosa

Lawod sang post-ofis, lawod sang post-ofis

Ang gin-agyan niya

[I went to fish at the banks of love. I prepared a bait florid with words. I sailed on rose-coloured packets

Across the span of the post-office.

There, I have navigated.] 
Other works, however, provide more straightforward narratives. For instance, in the popular song, "Kanogon", Pirot expressively describes the pain of rejection, frustration and longing for a romance that is spoilt.

Kanogon, kanogon sang gugma kanogon

Kung ako mag-nobya na dili madayon

Kung magsugata-ay sa mga dalanon

Isira bugno magyuhum sa akon

[Oh, woe! A love that is spoilt!

I only love in complete dismay.

Even if we meet at the crossway

You never returned a smile for once.]

The figurative allusion of sentiment in the song, nonetheless, has its parallels in Ilonggo and West Visayan social life that the song narratives become likely expressions of the folk ethos and native realities. Customarily, sentiment is typically operationalized through the buut (will, being), ${ }^{8}$ a Visayan concept of self and personhood that regulates and prompts social action. In social affairs, i.e. courtship, a person is compelled to take accountability in appeasing the buut in the occasion that he had aggrieved a person's mental and emotional being whether intentionally or not. Thus, in the song sample "Kanogon", expressing dismay for a defeated buut is in reality an indirect appeal to the woman to reevaluate her feelings and reprieve the injured buut of the singer. In other instances, the song may take form as a pabati-bati (rebuke) or, in some cases, as a form of mockery, especially for individuals who had become estranged or insensitive after an ill-fated romance. With these other messages notwithstanding, both narratives would nonetheless continue to describe the quixotic sentiment of the singer who implicitly accepts his loss yet still hopes for reconsideration.

The buut, however, is reprieved if the message is desensitised with malice. As there are some emotion-provoking songs which may hurt the buut, folk musicians always seek the indulgence and offer explicit apologies to the audience for any disquieted feeling they might have felt during the performance. As such, the act rectifies the buut of the listeners in consideration to the singer's plea. In the closing section of the komposo sample below, indulgence from the buut is explicitly asked.

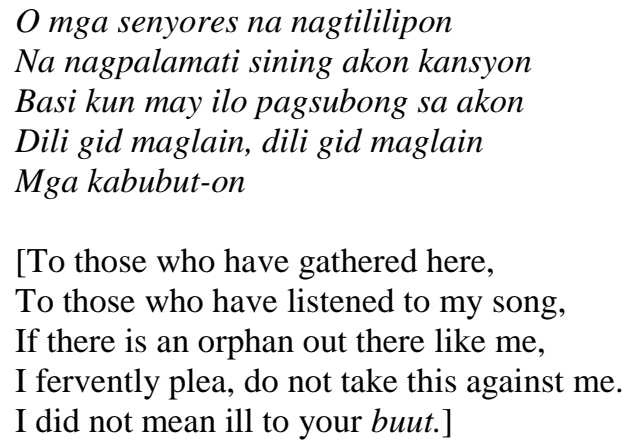

[To those who have gathered here, To those who have listened to my song,

If there is an orphan out there like me,

I fervently plea, do not take this against me.

I did not mean ill to your buut.]

\section{The Confluence of Pirot's Music and Banda Music Practice}

Because of its intersection with folk aesthetics, Pirot's music was easily integrated to contemporary folk music practice. Works such as "Ako Ang Namunit", for instance, were readily appropriated by musicians in the region and now are very much staple pieces in folk music and banda repertoire. These had become a common folk tune sung privately for leisure in the household and even in makeshift performances in public spaces such as community markets. ${ }^{9}$ Meanwhile, pieces like "Kanogon" were adopted into various renditions, such as Domingo Taborete's bandyo version, where the musician borrowed the melodic fragments of the original and infused them into his personal and stylistic lyricism (Figure 6). While this is a typical harana melody, Domingo labels this as a traditional kansyon, a type of love song generally sung by a soloist. ${ }^{10}$ 

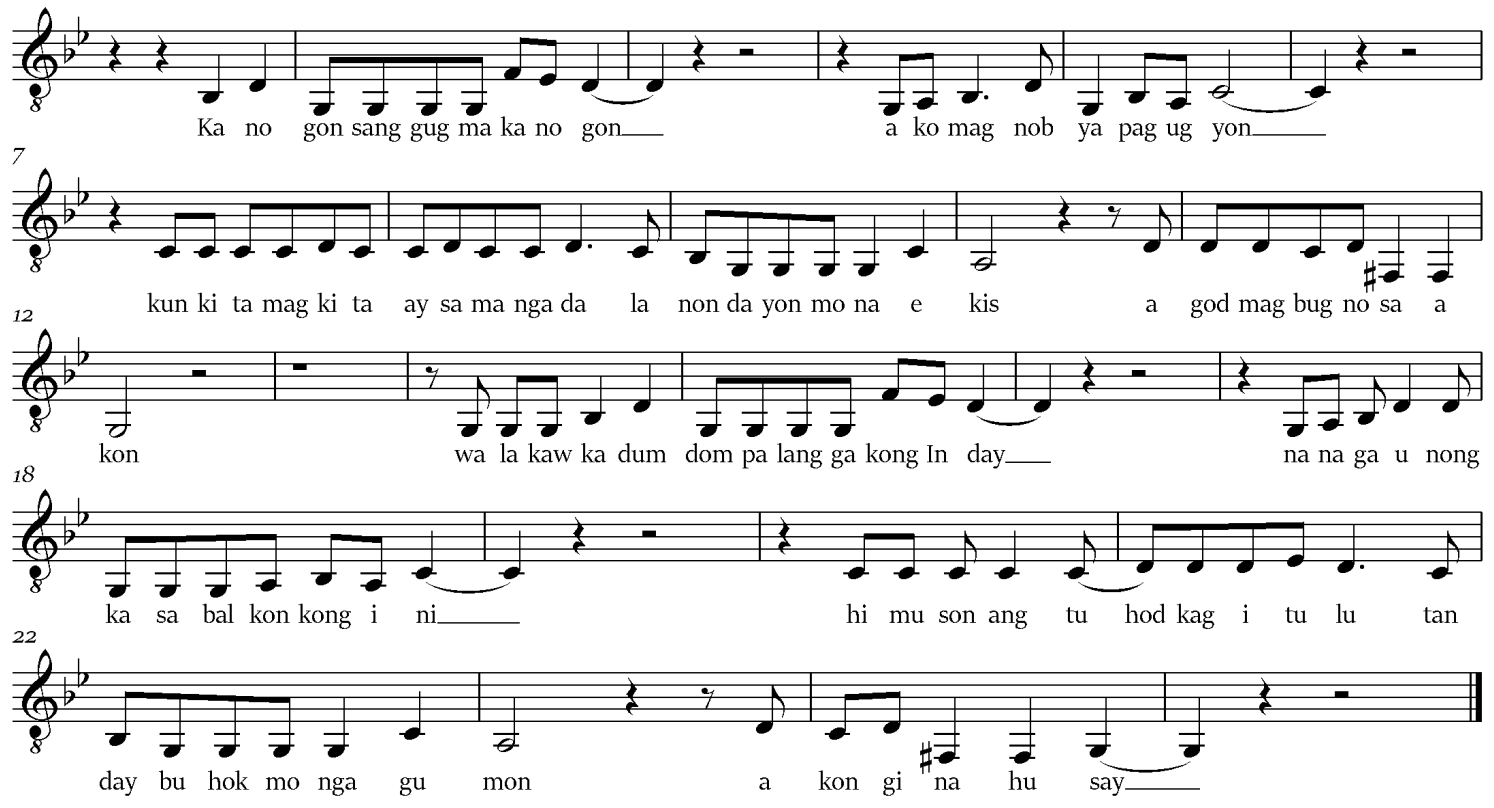

Figure 6. Rendition of 'Kanogon' by Domingo Taborete.

Drawing inspiration from folk history, the song titled "Purchase of Panay" is perhaps one of the highly recognised komposo pieces interpreted by Pirot. ${ }^{11}$ Appearing as early as the late nineteenthcentury in Tomás Santarén's 1858 Historia de los Primeros Datos que Procedentes de Borneo Poblaron Estas Islas Filipinas, and reemerging in Angel Perez's annotations in Igorrotes in 1902 (Santarén, 1954) and in Pedro Monteclaro's disputed document Maragtas (1907), the narrative had been a popular source of myth, legend and/or history in Panay for generations. Sung in a mixture of Visayan and English languages, it describes the sojourn of several families from Borneo to the island of Panay and their brief encounter with the Ati, the Negrito indigenous inhabitants of the island, in the thirteenth century. In the narrative, the ten chiefs of the barangay (family/kin unit) lead by Datu Puti exchanged a golden hat and a piece of necklace for the land governed by the Ati chief, Marikudo, with a conditional agreement that the newcomers settle along the coast and plains while the Negrito bands occupy the more interior sections of the island. This is followed by the division of the island into three confederate states leaving the Ati displaced from their native land.

\author{
Sadtong thirteenth century \\ Ako gitu-aw history \\ Ang Borneo may kinagamo didto \\ Bangud sa isa ka Sultan \\ Makatunaw iya ngalan \\ Mapintas sa iya ginsakpan \\ Agud maglikaw sa gamo \\ 'ning datus sang Borneo \\ Sakay sa ila balangay \\ Litog ug uway \\ Ang ila mga ngalan \\ Sining datu nga natungdan \\ Pamati-i kay akon hinambitan
}

[In the thirteenth century,

According to history,

Borneo was in conflict

Because of a Sultan

Known as Makatunaw

Who was vicious to his people.

To avoid the quandary, 
Several chiefs in Borneo

Set sail with their ships

Made of wood and rattan.

These are the names

Of the referred datu.

Listen, and I will tell you]

Because of its popularity, it remains to be part of the repertoire among folk music circles. Banda musicians in southern Iloilo, for example, still continue to perform "Purchase of Panay" for recreation or in some instances at the bid of a visitor. In other cases, some members of the Panay Bukidnon indigenous cultural community in Central Panay highlands cites the song as a reference for their claims of Bornean ancestry. ${ }^{12}$ As such, Pirot in his evocative musical rendition of "Purchase of Panay" had relit the folk imagination which brought into consciousness a native past reifying not only the widely held belief on the origins of the people in Panay but also the image of a noble society that was consequently mutilated and laid to waste by the vestiges of colonisation.

Besides harana and komposo music, Pirot was also much-admired for his spontaneous renderings of banggianay (song jousts) where he would banter with charm, wit and humour against his Ati contender. Even though it is a very popular music form and enjoyed by the majority of his audience, only a few of Pirot's banggianay were recorded. As extemporaneous musical battles, these particular performances may span for a couple of minutes that were way beyond the limitations of available sound recording technology. Unlike Pirot's other songs, these compositions were not realised into recordings until much later with the development of new media. It is only in 2009 when Pirot published an album which introduced the song-piece, "Bulak Nahamut-an" (A Woman to Please).

Diin ka naghalin lalaking makahas

Diin ka nga du-og sining Pilipinas

Wala ka pa gani makapakilala

Nagpahayag kana sang baog mong gugma

Ang akon gugma dili lahog-lahog

Kaputli kag tampad di ang gaguyod

Kung indi pagsundan lahat na maniklod

Basi magkomitir sang tawag nga hikog

[Where have you come, daring man?

Where in the Philippines have you been?

You haven't even introduced yourself,

Yet, you have already professed your stale love.

Oh, my love is never a tease;

My intent is pure and sincere.

Yet, if you utterly reject my love,

I might commit to Death's embrace.]

Musically, this banggianay piece is comparable to other folk genres with its consistent use of melodic and harmonic minor modality, duple rhythm and strophic structure. Yet, unlike the harana and the komposo, its melody is more similar to known musical motifs typically performed in the sarswela, a type of vernacular theatre characterised by musical banters, intermittent round dances and theatrical drama playing around themes of traditional courtship (Figure 7). ${ }^{13}$ 


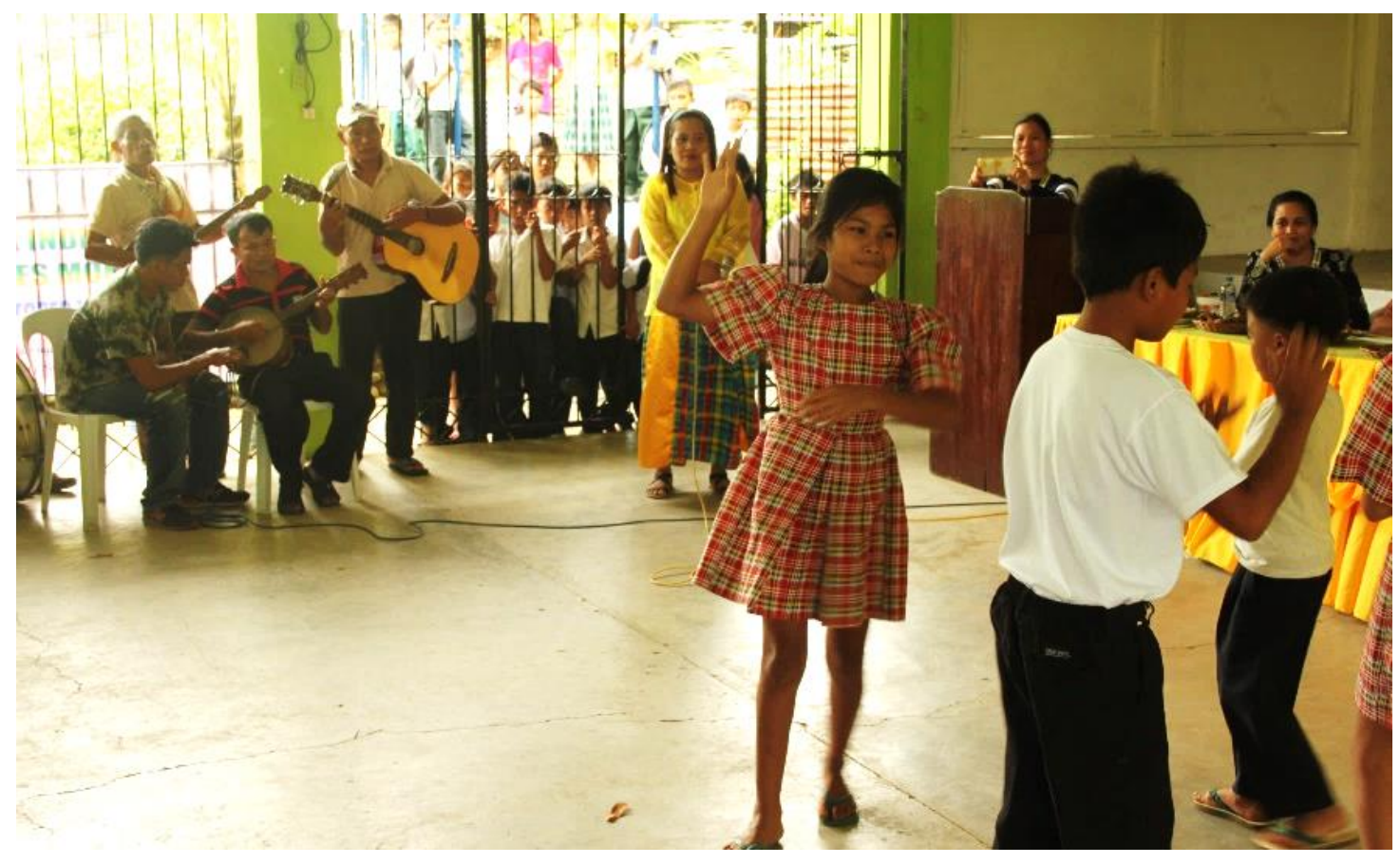

Figure 7. Sarswela performance of young school children with the Igtuble Indigenous Peoples String Band in 2017.

Of the two sarswela tunes I have documented, one in San Remigio, Antique and the other in southern Iloilo, the latter variant closely parallels Pirot's banggianay (Figure 8). On this, locals explicitly comment that the two styles are analogous by affirming "Hио, parareho lang na sila [banggianay and sarswela]; ang sarswela may saot lang" [Yes, they are the same; the sarswela, however, has dance]. ${ }^{14}$ Sarswela performances, however, are rarely performed organically in folk communities today. Of the few performances that had been done recently, most if not all were staged for institution-based activities or for agency-sponsored events.

Unlike the sarswela, banggianay still enjoys its popularity, albeit, in a more intimate way. Today, it is still performed during wakes, but rather in a more poetic form than its musical variant. Banda musicians in areas like Tubungan and Alimodian take pleasure in performing renditions built upon Pirot's song jousts in the same way that rural households revel in streaming songs like "Bulak Nahamut-an" in public using their home stereos and large trompa (sound boxes).

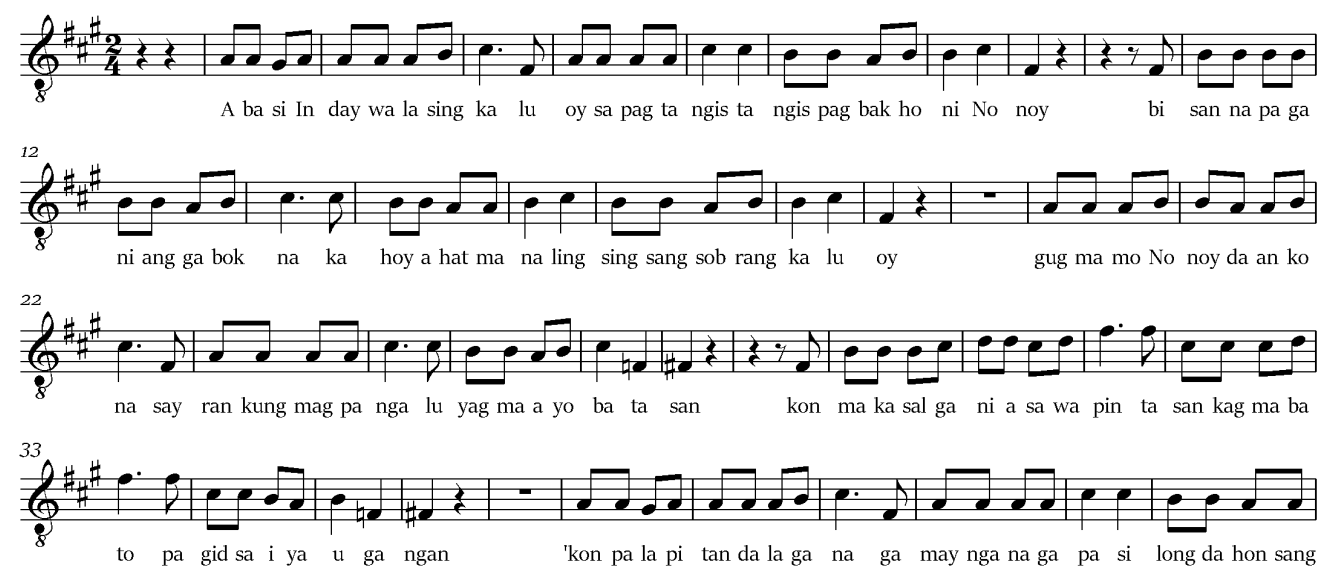

Figure 8. Sarswela music performed in Bulan-Bulan and Igpaho villages with a similar style to Pirot's banggianay. 


\section{“Traditionalising" Popular Music: The Banda Folk Repertoire as Indigenous Cultural Identity}

Pirot's popular music is undeniably very much assimilated to the musical and social lives of folk musicians. As discussed above, banda musicians have freely appropriated his music in their performances and rendered these within the folk repertory, a process which I call "traditionalisation". In context, this process may be understood as the adoption of musical practices, in this case Pirot's music, into musical categories deemed as folk by virtue of its musical "organicism" with folk genres (Onderdonk, 2009, p. 210).

Yet, considering the socio-cultural circumstances of banda performers today, traditionalising the music of Pirot also carries other ideological and practical implications particularly in the identity politics within indigenous cultural communities (ICCs). Compared to indigenous populations in northern and southern Philippines, i.e. Ifugao and Maranao, with more established ethnic identities, it is only recently that Panay cultural communities, specifically the Panay Bukidnon minority, had come forward as a distinct ethnic group. The group is relatively underrepresented - in the academia alone, scholarship is scant except for a few albeit sporadic representative works which include Jocano's (1968) pioneering anthropological work on the Sulod, Magos' (1996) sugidanon (epic) series and Muyco's (2016) exploration on the performance ideology known as sibod in Panay Bukidnon music-dance traditions. These works only represented a fraction of the diversity of Panay Bukidnon cultural groups. Individual communities have specific, social, cultural and political histories with some possessing a long-standing cultural memory, while others having relatively recent histories. It is only in 1997 that, with the ratification of Republic Act 8371 or the Indigenous Peoples Right Act (IPRA), the group had been formally recognised as an indigenous minority by law. Because of this, more robust support from national agencies as well as from academic institutions paved the way for the implementation of various cultural initiatives in which the Panay Bukidnon themselves have become key actors. Initiatives include the identification, establishment and promotion of indigenous knowledge, systems and practices particular to specific communities such as the babaylan (medium), binanog (hawk-eagle dance) and panubok (embroidery) culture of the Panay Bukidnon in Central Panay ${ }^{15}$ and the harana, komposo and the sinulog/sayaw (sword-play ritual) practices of the Panay Bukidnon in northern and southern Iloilo. It also led to the strengthening of local political structures as well as the institutionalisation of community-based learning spaces known as Balay Turun-an (Schools of Living Tradition). Indigenous elders and professionals were even enabled in the development and application of indigenous learning frameworks concomitant to the implementation of the Indigenous Peoples Education (IPEd) Programme by the Department of Education in 2011. These efforts provided avenues for empowerment raising "indigenous consciousness" and constructing a sense of identity.

This prompted Panay Bukidnon banda musicians to also participate in the process, which, through their ideas of tradition, made Pirot's popular works symbolic of local indigenous culture and identity. The way they approached the icon's works varied with respect to the social, geographical and historical circumstances of their communities. In Central Panay, Panay Bukidnon elders cite the "Purchase of Panay" as an explanation for their association to the Bornean datus. As an indigenous person with no distinguishable racial trait similar to the Ati, Sandigan, now in his sixties, articulates through song the authenticity of his origins and, with conviction, identifies himself with the Bornean settlers. While standing migration hypotheses on the Panay Bukidnon's origins exist, ${ }^{16}$ the narrative strongly resonates among indigenous communities that celebrate the story as a tradition in the same way that lowland urban and coastal communities express this as theatrical spectacles and festival reenactments.

Meanwhile, in other Panay Bukidnon communities, a select few of Pirot's songs received special distinction as illustrative examples of the indigenous musical repertory. Young Panay Bukidnon musicians of Libacao, Aklan, for instance, presented interpretations of Pirot's novelty song, "Mabugnaw Ang Talon", as their musical tradition during the 2019 Indigenous People's Month and IP Education Day celebration. ${ }^{17}$ Similarly, small banda groups such as the "Banda ni Ruben" in Tapaz, Capiz also perform some of icon's dinuma-an singles as a part of their musical inventory (Taton, 2018, field notes). The Panay Bukidnon in Tubungan, Iloilo, is even a more striking case that Pirot's music, such as "Kanogon", "Ako Ang Namingwit" and "Bulak Nahamut-an", have been integrated and are staple segments in their vocal and instrumental repertoire. Interestingly, apart from Pirot's songs, banda musicians also associate other popular songs coming from other regions, i.e. Max Surban's "Baleleng" 
and "Ang Gugma Sa Dalom Sang Lawa-an", in the category of dinuma-an. When asked what makes these songs traditional, Mabini, a banda gitara player, strongly quotes "Kay muna ang kultura kag tradisyon namon na mga IP" [That is the culture and tradition of an indigenous person] after performing a series of Pirot's and Surban's music for some guests.

\section{Contextualising Popular Music as a Canon and a Practice of "Tradition"}

"Tradition" is an elusive and particularly laden concept. Because of its implied practical utility as part of language, it is plagued with indefinite semantic meanings that it had been applied diversely, i.e. as canon, as standard, as a process, as performance, as culture, in the analysis of texts, cultures and societies in the humanities and social science disciplines (Schippers, 2006). Its early and conservative usage, particularly in folklore, had been predicated by ideas of cultural progress that projected pastoral societies and folk practices in a timeless, invariant and immutable image of the past. Moreover, it underscores the transmission, particularly oral, of cultural materials identified simply as folklore and its canons with consistency and continuity across space and through time (Georges \& Jones, 1999; Shils, 1971).

Similarly, in music studies, tradition's association to notions of folk canon and pastoral imagery largely remains one of the persistent, if not more pronounced, strands of meaning given the heuristic value it provides, more specifically, in positioning tradition in contrast with civilisation and modernity. This distinction was more apparent with the invention of "folk" and "art" music categories that emerged with the rise of nationalist sentiments in eighteenth-century Europe (Gelbart, 2007). Coming out of the political and cultural disarray of the time, nationalists rallying for political unity and cultural independence sought for a common "cultural property" which embodies the national spirit (Onderdonk, 2009 , p. 207). As a consequence, they turned their gaze towards "nature" particularly in the music and poetic traditions-the folklore-of pastoral societies (Ben-Amos, 1984, p. 100) which became a metaphor for an unrecoverable innocence and timelessness of the past (Onderdonk, 2009). However, these traditions appear nascent and irrational-qualities that apparently do not fit the rational ethos, aesthetic philosophy and urban sophistication of an emerging national polity. This led to the aesthetic elevation of folk music into socially-sanctioned artistic bodies of work and, thus, the creation of a collective national "art music" canon (Gelbart, 2007). In the words of Reily (2007), "the very concept of "art" could only emerge in contra-distinction to another body of expressive forms, "folklore", the one of universal validity, the other of purely local relevance and intelligibility" (p. 3).

Bohlman (1988), however, avows that the "restrictive caveats of earlier scholarship" (p. xvi), with its premises centred on pastorality and orality, entail a discourse that does not consider the diversity of musical expressions in the modern world. While folk and art music were generally considered "popular" in their respective contexts, Bohlman, in particular, is referencing to the range of hybrid and differentiated music styles that grew in urban centres in the late nineteenth century. These new "popular" music styles appeared to have had a cosmopolitan orientation, a lack of aesthetic sophistication and an ephemeral quality which did not fit the earlier semantics of folk and art tradition categories. By the time commercial recordings became a viable enterprise, popular music had become a product of the music industry. It was its very construction as a commodity that distinguished it from folk and art music. Popular music, as a representative of progress and modernity, thus, runs antithetical to previous notions on tradition.

Notwithstanding these connotations, popular music as expressive articulations had in time established its respective sound repertoire and, like folk and art music, constituted bodies of works that are now transmitted and practised in the local-global arena. As such, other scholars like Brandellero et al. (2014) posit that popular music is a form of heritage as much as it is a tradition with a particular musical identity itself. For them, popular music, like any other types of musical expression, is a social practice that involves a diversity of individual and institutional actors. These actors are significant as they provide the necessary "legitimising discourse" ranging from "personal and collective attachment and memory to commercial endeavours rebranding and canonising the musical pasts" (p. 220). In brief, musical actors provide the conditions by which popular music and its various derivatives may be constituted as heritage and/or tradition of a people.

From the discussion, it can be gleaned that defining "tradition" as a categorical referent for folk, art and popular music expressions is a particularly fluid and equally nebulous process. With regards to 
this 'practical fluidity', Ben-Amos (1984) perhaps is right to say that tradition is an "object of conscious creativity" where a society "creates its own traditions through the selection of historical events and heroes, and even through the invention of a past" (pp. 114-115). Meanwhile, in societies with poorly established or absent historical bases, tradition may emerge as a "mode of thought", if not an ideological category, which may be reconfigured into creative solutions (Bronner, 2016, p. 14). Bronner (2016) even extends this thought in the modern context by arguing that invoking "tradition" carries multifaceted implications that demonstrate "individualised permutations of traditional knowledge in repeatable, variable practices" or "thinking behind the formation of traditional knowledge back from practices" (p. 18). Thus, it is more apt to treat folk, art and popular music expressions as 'folk categories' (Bohlman, 1988), or at best as a creative bricolage of musical idioms that proffer new stylistic possibilities as well as ways in which people make musical choices and personal, community, and national interests may be anchored. Tradition as a practice, therefore, implicates the ascendancy of human agency over historical authority and suggests that tradition is self-consciously invented (Linnekin, 1983, p. 241) and/or reinvented (Hobsbawm \& Ranger, 1992).

In this study, the way performers render the popular music of Pirot in the context of "tradition" and the means they integrate this context to the construction of indigenous identity suggest three points. First, there is a vague boundary between musical categories that folk music is readily appropriated, transmuted and rendered to popular music in the same way that popular music becomes identified with the folk. Second, there is the primacy of agency in musical categorisation and even in the construction of an "authorised heritage" or tradition (Smith, 2006). Lastly, using notions of "tradition", musicians legitimise an indigenous identity relative to their particular social, cultural and historical contexts. As key actors in the process, banda musicians have conflated Pirot's works as tradition owing to the music's "idiomatic intelligibility" (Szabolcsi, 1964) with the more familiar folk genres in the region. As a product of the music industry, Pirot's music was transformed into a hybrid "mass culture species of folklore" (Dorson, 1978, p. 42) that is betwixt in a liminal space and in a "categorical blur" between folklore and mass-mediated popular culture. Notwithstanding, Pirot's music still appeals to tradition that teases one's imagination into visualising the pristine and idyllic atmosphere and the simple and cyclical rhythms of rural society. It finally offers a delightful "conversation of images" (Singer, 1972, p. 12) of sound and narrative flooding the senses with nostalgia and bringing to life the joys, difficulties and triumphs of folklife. As such, with its obvious use of regional music heritage, Pirot's music was assimilated if not outright appropriated in banda practice to the taste of the folk music performers. Thus, through the banda musician's "consensual reception" (Shils, 1971, p.130), the popular music of Pirot had become legitimised as a part of folk tradition and as a part of an indigenous cultural repository and practice.

Relatedly, the "traditionalisation" of Pirot's popular music is also predicated by an emerging regional "indigenous consciousness" that parallels the cultural valorisation of indigenous and intangible heritage in national and academic discourse. Considering that this ethos came in relatively late (established in the early 2000s) among the Panay Bukidnon, building a traditional repertoire became a cultural if not a political preoccupation. With the increased autonomy as well as rights to selfdetermination accorded to the indigenous peoples in the country, community musicians invested on similar endeavours that, the institutionalisation of banda groups such as the Igtuble Indigenous People String Band in Tubungan ${ }^{18}$ had facilitated in the recreation of their banda music canon. As Williams (1961) and Hymes (1975) claim, identity formation hinges on how "tradition" is constructed as a symbolic "past". This is established through purposeful activities and social interactions which, with repeated practice, as Bronner (2016) puts it, strengthen notions of self. While banda musicians represent a minority, Bronner (2016) following Bauman (1999) reminds that "the individual construction of self" is a "cultural praxis" (p. 21). Nonetheless, their participation in the promotion of "individualised "traditions", as Bronner (2016) explains, "represent a broader expectation in modern societies that individuals create an identity out of many cultural options and demonstrate this identity in practices that might only be known to the individual" (p. 21). Practising "tradition", as exemplified by the "traditionalised" popular music of Pirot, then, had been crucial in the demonstrating and reifying the folk musician's feelings of solidarity and, in turn, indigenous identity.

Anchoring indigeneity to a practice of "tradition", in this sense, is constitutive of the way dinuma-an as a music category is articulated. That, the dinuma-an (tradition and the traditional) becomes a performance of cultural memory within a self-conscious idea of historic time. Through 
practice, banda musicians, in their personal capacities, continuously reify and legitimise their cultural ethnicity by using a model of tradition that conflates musical performance and sense of self. Using the confluence of the traditionally folk and the historically popular music as "tradition", Panay Bukidnon banda musicians construct, transform and eventually recreate their indigenous identity through music.

\section{Conclusion}

In the discussion, I have argued that the way banda musicians understand tradition is defined by and is constitutive of practice. The content of tradition, whether sourced from antiquity or in popular practice, is arguably permeable as meaning becomes fluid across time. For the banda musicians, Pirot's music is representative of how categories are reconfigured from their idealised notions of dinuma-an and of folk music. This notion, however, is entangled with cultural politics and indigenous modernity and may provide focal points for reflection particularly on the region's music history.

\section{Acknowledgements}

I wish to recognise all the banda musicians in Tubungan, Iloilo for graciously allowing me to record their music, in particular Sotero Taghap, Mabini Tagurda and Domingo Taborete, as well as the banda in Panuran, Lambunao, Iloilo and in Tacayan, Capiz. I also offer my gratitude to Virgilio Petcheller and family for the warm accommodation. Special thanks to my co-researcher, Fely Araña, and to other focal persons namely, Emelyn Tano, Marilyn Talha and Orlyn Gallo. I also want to thank the community heads, Rodolfo Caballero, Eduardo Paneza, Rodrigo Tacaisan Jr. and Recto Taghap for the support; and to Miguel Davao for reviewing the essay. This article is a result of the research titled, "Lanton kag Kuskos kang Balatyagon: The Traditional Music of the Banda of the Tubungan Bukidnons in Iloilo" funded by the National Commission for Culture and the Arts (NCCA), BR 2018-134. Also, this paper is an expansion of the paper titled, "Reconfiguring the Folk and the Popular: Traditionalisation of Music Genres in Tubungan Bukidnon Banda Repertoire" read at the Ethnographies of Philippine Auditory Popular Cultures (EPAPC) National Conference in Ateneo de Manila University, September 4-6, 2019.

\section{Endnotes}

1 Maps from Google Maps, https://commons.wikimedia.org/wiki/File:Panay_Island_Red.png and https://commons.wikimedia.org/wiki/File:Ph_fil_iloilo.png

${ }^{2}$ Compared to the rondalla, comprehensive studies on the history of the banjo in the Philippines are scant. Notwithstanding this seeming lacuna in organological research, there are several accounts which indicate the presence of the banjo in the country. For example, the banjo was mentioned in James Hopper's short story, "Banjo Nell" (1910, pp. 15-16, 26-27), which illustrate a young bourgeois woman who brought the instrument to the Philippines. Meanwhile, National Artist Lucio San Pedro (1913-2002) was known to have been proficient in playing the banjo. Antonio Hila (1998) writes, "He would play ... so skilfully that he was hailed as the banjo player during his elementary days at the Pasig Elementary School” (p. 308). In another account, Keppy (2019) notes of "orientalist acts" which include the performance of Dudu, described as the "famous Moro banjoist" who is assisted by his "Comparsa of Moros from Jolo" in 1922 (p. 62).

${ }^{3}$ Hit singles of Visayan pop music icons such as Max Surban's "Baleleng” (A Person), "Ang Gugma Sa Dalom Sang Lawa-an" (Love Under the Laua-an Tree) and "Turagsoy" (A Kind of Fish) became very popular. Today, live radio programs, i.e. in Bombo Radyo, are still being held with a new generation of harana and komposo singers.

${ }^{4}$ Generally, banggianay is defined as "to quarrel, dispute, wrangle, have words, altercate" (Kaufmann, 1934, p. 55). In music, it refers to the musico-poetic altercation of verses. This may suggest that banggianay is a process common to many strands of musical repartees.

${ }^{5}$ Pirot claims that his shows with Villanueva drew in a huge crowd each night in the home station of Bombo Radyo Iloilo.

${ }^{6}$ He collaborated with composers M. Encarnacion, M. Jadraque and E. Balboa among others.

${ }^{7}$ Photos screen-captured from Wilbert's Music Library; Jubell Record's LP Pirot (Cebuano Album) cover in partzmarbelt_2.0 channel in YouTube; and https://humandiscoveries.wordpress.com/2016/05/18/pirot-theharanista/

${ }^{8}$ Theoretically, buut is an inner sense of personhood composed of physical, affective and cognitive dimensions (Villan, 2013). It is comparable to the Tagalog loob and Ilokano nakem (Mercado, 1972). 
${ }^{9}$ In some rural areas, visually-impaired musicians hold performances in markets.

${ }^{10}$ Kansyon comes from the Spanish cancion meaning "song". While both are understood as love songs, banda musicians differentiate harana from kansyon as a repartee while the latter is a solo piece. Interview with Domingo Taborete and Sotero Taghap, April 2016 and December 2018.

${ }^{11}$ The song also had other versions like the Ati "Pagbaylo ke Panay" (Barter of Panay).

${ }^{12}$ Interview with Romulo and Rodolfo Caballero, Panay Bukidnon cultural masters in Calinog, Iloilo, August 2017 and March 2018.

13 Folk sarswela sprang from Hispanic zarzuela/sarswela popularly staged for urban elite entertainment (Fernandez, 1978).

${ }^{14}$ Interview with Fely P. Araña, Indigenous Peoples Community Focal Person in Tubungan, Iloilo, April 22, 2020.

${ }^{15}$ The Panay Bukidnon group is a cluster of Kinaray-a-speaking communities which depend on upland agriculture for subsistence.

${ }^{16}$ For a discussion on the three major inward migration hypotheses, see David Gowey's (2016) article, Palawod, Pairaya.

${ }^{17}$ See https://www.youtube.com/watch?v=kexFzP7HRa0

18 The banda was established in 2007.

\section{References}

Bauman, Z. (1999). Culture as praxis. Sage.

Ben-Amos, D. (1984). Tradition and identity: The seven strands of tradition: Varieties in its meaning in American folklore studies. Journal of Folklore Research 21, (2/3), 97-131.

Bohlman, P. (1988). The study of folk music in the modern world. Indiana University Press.

Brandellero, A., Janssen, J., Cohen, S. \& Roberts, L. (2014). Popular music heritage, cultural memory and cultural identity. International Journal of Heritage Studies, 20 (3), 219-223.

Bronner, S. (2016). Toward a definition of folklore in practice. Cultural Analysis, 15 (1), 6-27.

Buenconsejo, J. (2019). Songs for the masses: Humor in Max Surban's folk urban ballads. Paper read at Kritika Kultura:: Ateneo de Manila University.

Cainglet, E. C. (1981). Hispanic influences on the West Visayan folk song tradition of the Philippines, 2 volumes (Unpublished doctoral dissertation). University of Adelaide, Australia.

Canave-Dioquino, C., Santos, R. \& Maceda, J. (2008). The Philippines. In T. Miller \& S. Williams (Eds.), The Garland Handbook of Southeast Asian Music (pp.415-445). Routledge.

Colon, J. C. (n.d.). Tubungan: A history (1938-2013) (Manuscript). Tubungan LGU.

Doromal, G. (1988). The traditional music of Iloilo. UP Visayas Studies Program.

Dorson, R. M. (1978). Folklore in the modern world. In R. M. Dorson (Ed.), Folklore in the modern world. Mouton Publishers.

Fajardo, L. (1961). Visayan folk dances, vol. 1. National Bookstore, Inc.

Fernandez, D. (1978). The Iloilo Zarzuela, 1903-1930. Ateneo de Manila University Press.

Gelbart, M. (2007). The invention of 'folk music' and 'art music': Emerging categories from Ossian to Wagner (New Perspectives in Music History and Criticism). Cambridge University Press.

Georges, R. \& Jones, M. O. (1999). Folkloristics: An introduction. Indiana University Press.

Gowey, D. (2016). Palawod, Pa-iraya: A synthesis of Panay Bukidnon inland migration models. https://www.academia.edu/29928804/Palawod_Pa_iraya_A_Synthesis_of_Panay_Bukidnon_Inland_M igration_Models

Guzman-Bravo, J. A. (1978). Mexico, home of the first musical instrument workshops in America. Early Music, 6 (3), 350-355.

Hila, A. (1998). Lucio D. San Pedro: The creative nationalist. In The national artists of the Philippines (pp. 307318). Cultural Center of the Philippines and Anvil Publishing.

Hopper, J. (1910). Banjo Nell. Collier's 44 (23), 15-16, 26-27.

Hobsbawm, E. J. \& Ranger, T., (Eds.). (1992). The invention of tradition. Cambridge University Press.

Hymes, D. (1975). Folklore's nature and the sun's myth. Journal of American Folklore, 88, 345-369.

Irving, D. R. M. (2010). Colonial counterpoint: Music in early modern Manila. Oxford University Press.

Jocano, F. L. (1968). Sulod society: A study in the kinship system and social organization of a mountain people of Central Panay. University of the Philippines Press.

Kaufmann, J. (1934). Visayan-English Dictionary. La Editorial.

Keppy, P. (2019). Tales of Southeast Asia's Jazz Age: Filipinos, Indonesians and popular culture, 1920-1936. National University of Singapore Press.

Linnekin, J. S. (1983). Defining tradition: variations on the Hawaiian identity. American Ethnologist, 10, 241252.

Magos, A. (1996). The Sugidanon of Central Panay. Edukasyon: Harnessing Indigenous Knowledge for 
Education, 117-140. Education Resource Program Monograph.

Mercado, L. (1972). Reflections on buut-loob-nakem. Philippine Studies, 20 (4), 577-602.

Monteclaro, P. (1950). Maragtas (E. Abiera, Trans.). Chicago, Illinois: s.n. (Original work published 1907).

Muyco, M. C. (2016). Sibod:Ideology and expressivity in Binanog dance, music, and folkways of the Panay Bukidnon. Ateneo de Manila University Press.

Onderdonk, J. (2009). Review on Matthew Gelbart's The invention of "folk music" and "art music": Emerging Categories from Ossian to Wagner. Current Musicology, 87, 207-217.

Pfeiffer, W. R. (1975). Music in the Philippines. Diliman Music Foundation, Inc.

Reily, S. A. (2007). Folk music, art music, popular music: What do these categories mean today? https://www.academia.edu/178279/Folk_Music_Art_Music_Popular_Music_What_do_these_categorie s_mean_today

Rubio, H. (1977). A brief survey of band development in the Philippines. In A. C. Bataclan (Ed.), Philippine Bands (pp. 4-5). National Band Association of the Philippines.

Santarén, T. (1954). Bisayan accounts of early Bornean settlements in the Philippines recorded by Father Santaren (E. Fox, Trans.). Philippine Studies Program, University of Chicago.

Schippers, H. (2006). Tradition, authenticity and context: the case for a dynamic approach. British Journal of Music Education, 23 (3), 333-349.

Shils, E. (1971). Tradition. Comparative Studies in Society and History, 13 (2), 122-159.

Smith, L. (2006). Uses of heritage. Taylor \& Francis.

Singer, M. (1972). When a great tradition modernizes. Praeger.

Stevenson, R. M. (1971). Music in Mexico. Thomas Y. Crowell.

Suarez, P. (1971). Ilonggo folk dances. Central Philippine University.

Szabolcsi, B. (1964). Folk music, art music, history of music. Notes, Second Series, 21 (4), 503-510.

Tan, A. J. (1981). A study of the Hiligaynon ballad or composo (Unpublished Master's thesis). Ateneo de Manila University.

Talusan, M. (2009). Gendering the Philippine brass band: Women of the Ligaya Band and National University Band, 1920s-1930s. Musika Jornal, 5, 33-47.

Taton, J. Jr. (2019). Lanton kag kuskos kang balatyagon: The traditional music of the Tubungan Bukidnon Banda in Iloilo (Research Manuscript). National Commission for Culture and the Arts.

Villan, V. C. (2013). Lawas, buut, patugsiling, 'ag dungan: Isang pag-unawa sa papel ng kinagisnang sikolohiya sa kasaysayang kolonyal at himagsikang Pilipino sa Panay, 1896-1898. Daluyan: Journal ng Wikang Filipino, 19 (2), 73-110.

Williams, R. (1961). The long revolution. Chatto \& Windus.

\section{Biography}

Jose R. Taton, Jr. is an assistant professor teaching music, arts and humanities at the University of the Philippines Visayas. He finished his Master of Arts, major in Ethnomusicology at Philippine Women's University where he is currently pursuing doctoral studies in music, major in Ethnomusicology. His research interests include festival music studies, ethnochoreology and indigenous/cultural pedagogy. At present, he is undertaking research on indigenous organology, vocal music and dance practices among the Panay Bukidnon people living in central and southern highland areas of Panay Island. 